\title{
EFFECT OF SALINITY AND SODICITY STRESSES ON PHYSIOLOGICAL RESPONSE AND PRODUCTIVITY IN HELIANTHUS ANNUUS
}

\author{
Fatma Aly Farghaly, ${ }^{*}$ * Abeer Ahmed Radi, ${ }^{1}$ Dalia Ahmed Abdel-Wahab, ${ }^{2}$ \\ and AfaF MOHAMEd Hamada ${ }^{1}$ \\ ${ }^{1}$ Botany and Microbiology Department, Faculty of Science, Assiut University, \\ 71516 Assiut, Egypt \\ ${ }^{2}$ Botany Department, Faculty of Science, Assiut University, New Valley, Egypt
}

(Received: May 6, 2015; accepted: October 7, 2015)

\begin{abstract}
Soil salinity and sodicity (alkalinity) are serious land degradation issues worldwide that are predicted to increase in the future. The objective of the present study is to distinguish the effects of $\mathrm{NaCl}$ and $\mathrm{Na}_{2} \mathrm{CO}_{3}$ salinity in two concentrations on the growth, lipoxygenase (LOX) activity, membrane integrity, total lipids, yield parameters and fatty acids (FAs) composition of seeds of sunflower cultivar Sakha 53. Plant growth, LOX activity and malondialdehyde (MDA) content were reduced by salts stresses. On the contrary, salinity and alkalinity stress induced stimulatory effects on membrane permeability, leakage of UV-metabolites from leaves and total lipids of sunflower shoots and roots. Crop yield (plant height, head diameter, seed index and number of seeds for each head) that is known as a hallmark of plant stress was decreased by increasing concentrations of $\mathrm{NaCl}$ and $\mathrm{Na}_{2} \mathrm{CO}_{3}$ in the growth media. Fatty acid methyl esters (FAME) composition of salt-stressed sunflower seeds varied with different levels of $\mathrm{NaCl}$ and $\mathrm{Na}_{2} \mathrm{CO}_{3}$.
\end{abstract}

Keywords: Salt stresses - Helianthus annuus - lipoxygenase - membrane integrity - fatty acids

\section{INTRODUCTION}

Soil salinity is mainly due to the accumulation of $\mathrm{NaCl}$ and alkaline soil which latter is mainly caused by the accumulation of $\mathrm{NaHCO}_{3}$ and $\mathrm{Na}_{2} \mathrm{CO}_{3}$ [12]. Salt-affected soils have been categorized into three different types: saline, saline-alkali, and alkaline soils depending on the total concentration of soluble salts they possess, $\mathrm{pH}$ of the soil solution, and exchangeable sodium percentage of the soil [26]. Generally, the effects of salt stress on plant growth involve osmotic and specific ion effects, the former mainly dependent on salt concentration [20]. Previous studies indicated significant differences between the stress induced by neutral salts and that induced by alkaline salts, either in their mechanisms of action and/or in the physiological responses of the plants [9]. One of the prominent effects of salinity is the peroxidation of lipids and loss of membrane integrity attributable to reactive oxygen species (ROS), resulting in metabolic disturbance, lipid peroxidation and chlorophyll breakdown [29]. The possible causes of membrane injury owing to salinity was speculated

\footnotetext{
*Corresponding author; e-mail address: Fatmaadel2003@yahoo.com
} 
to be the decrease in membrane fluidity and loss of function because of lipid peroxidation, the extent which can be measured via the level of MDA content [1]. On the other hand, LOXs are responsible for membrane degradation, because they catalyze the deoxygenating of unsaturated FAs (UFAs) producing hydroperoxy saturated FAs that are toxic to the cell. Many reports indicate that changes in the content of UFAs can improve plant tolerance to environmental stresses such as cold, heat and drought [13].

Salt stress was shown to change the quantity and quality of seed oil of different oil-seed crops [23]. Pathway analysis revealed that lipid metabolism plays an important role in shoots and roots tissue of salt tolerant genotype to resistant salt stress [8]. Sunflower is an important oil-seed crop supplying about $13 \%$ of the total edible oil produced globally [27]. Only 5.4\% of land resources in Egypt represent intensive cultivated land, and about $40 \%$ of it is subjected to salinity, sodicity and water logging problems that are known to have deleterious effects on plant growth and productivity [15].

Thus, our goal was mainly to assess the possible tolerance mechanisms that relevant to metabolic and physiological responses of Helianthus annuus cultivar (cv.) Sakha 53 grown in sand cultures supplied with different concentrations of two salts $\left(\mathrm{NaCl}\right.$ and $\left.\mathrm{Na}_{2} \mathrm{CO}_{3}\right)$.

\section{MATERIALS AND METHODS}

Two experiments were conducted in a greenhouse and repeated twice in two independent processes. Four replicates were used for each treatment.

\section{Short duration treatment}

Sunflower sterilized seeds were planted in pots filled with air-dried and cleaned quartz sand, watered with a Hoagland's solution [10] and kept approximately at $100 \%$ field capacity. Preliminary experiments were carried out using different concentrations of $\mathrm{NaCl}$ and $\mathrm{Na}_{2} \mathrm{CO}_{3}$ to detect the osmotic and toxic concentrations [21]. Tenday-old seedlings were subdivided into three subsets: The first subset without salts (control), the second treated with 80 and $160 \mathrm{mM} \mathrm{NaCl}(\mathrm{pH} 6.60$, EC 7.23) and the third treated with 10 and $40 \mathrm{mM} \mathrm{Na}_{2} \mathrm{CO}_{3}$ (pH 6.65-7.07, EC 10.03-11.31). Leaves and roots (35-day-old) were harvested and stored at $-80{ }^{\circ} \mathrm{C}$. The dry weight (DW) was determined by drying the shoots and roots tissues for 48 hours at $70^{\circ} \mathrm{C}$.

\section{Assay of lipoxygenase activity}

Lipoxygenase (LOX; EC 1.13.11.12) activity was assayed spectrophotometrically [17]. The increase in absorbance was monitored at $234 \mathrm{~nm}$ wavelengths. 


\section{Determination of lipid peroxidation}

Lipid peroxidation was determined by measuring MDA formation using the thiobarbituric acid (TBA) reaction [14]. The MDA concentration was determined using extinction coefficient of $155 \mathrm{mmol} \mathrm{l}^{-1} \mathrm{~cm}^{-1}$.

\section{Electrical conductivity and UV-metabolites}

The leaf discs were rinsed and placed in closed vials containing $10 \mathrm{ml}$ of deionized water for $24 \mathrm{~h}$, subsequently EC of the solution was determined. Samples were then autoclaved at $120{ }^{\circ} \mathrm{C}$ for $20 \mathrm{~min}$ and the last $\mathrm{EC}$ was obtained after equilibration at $25^{\circ} \mathrm{C}$. The proposed formula [25] was used to determine EC \%. The leakage of UV absorbing metabolites was determined using the same solution of conductivity measurements [22].

\section{Determination of total lipids}

Determination of lipid content in sunflower tissues was carried out $[11,34]$. The pink colour was read at $490 \mathrm{~nm}$.

\section{Long duration treatment}

Sunflower seeds (10) were planted in $5 \mathrm{~kg}$ sieved air-dried clay and sand (2:1 by volume) soil, irrigated with water and kept at approximately $100 \%$ of the field capacity. Seedlings (10-day-old) were irrigated with salinized water $(80,160 \mathrm{mM} \mathrm{NaCl}$ and $10,40 \mathrm{mM} \mathrm{Na} \mathrm{CO}_{3}$ ) and left to grow under natural conditions for 120 days. Plant height, head diameter, seed index of 100 seeds weight and the number of seeds in each head were determined.

\section{Analysis of fatty acids in sunflower seeds}

Extraction of FAs from seeds and detection was followed [6]. FAME were analyzed using GC/MS, Agilent Model 7890 N/5975B [column, DB, $5 \mathrm{~ms}$, Agilent form $(30 \mathrm{~m}, 0.25 \mathrm{~mm}, 0.25 \mu \mathrm{m})]$ in the Analytical Chemistry Unit, Assiut University. A library Wiley and Nist was used for peak identification and instrument calibration.

\section{Statistical analysis}

Statistical analysis was carried out by using the ANOVA procedure of the sigma stat package (SPSS. Inc., USA), and treatment means were compared by the Tukey's test. 


\section{RESULTS}

\section{Total growth}

Plant growth and development are adversely affected by salinity. The dry matter yield of sunflower seedling showed a marked decrease as the levels of $\mathrm{NaCl}$ or $\mathrm{Na}_{2} \mathrm{CO}_{3}$ were increased (Fig. 1). The adverse effects of salinity or alkalinity stress were clearly demonstrated by plants treated with the higher concentration of the applied salts.
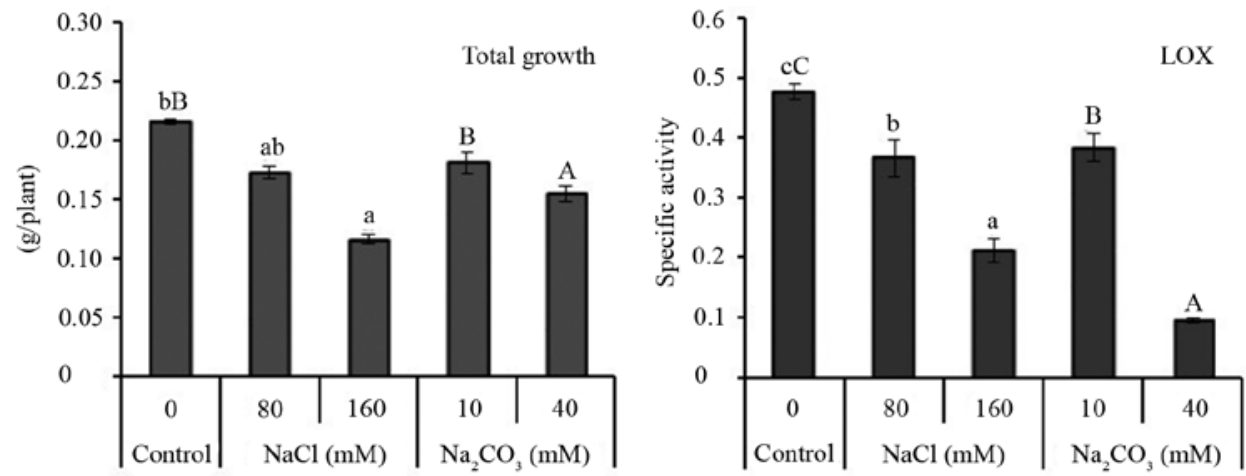

Fig. 1. Total dry weight (g/plant) and lipoxygenase specific activity (LOX) of sunflower plant (35-dayold) as affected by two concentrations of $\mathrm{NaCl}$ and $\mathrm{Na}_{2} \mathrm{CO}_{3}$. The results are means of four replicates $(+\mathrm{SE})$. Bars carrying different letters are significantly different at the 0.05 level

\section{Lipoxygenase activity}

The results shown in Figure 1 reveal that LOX activity was significantly decreased in sunflower leaves due to salinity or sodicity effect, compared with the absolute controls.

\section{Malondialdehyde content (MDA)}

MDA content was measured as a level of membrane lipid peroxidation. A noticeable reduction in the MDA content was observed in leaves and roots of the $\mathrm{NaCl}$ and $\mathrm{Na}_{2} \mathrm{CO}_{3}$-stressed sunflower plants, compared to absolute controls (Fig. 2). 

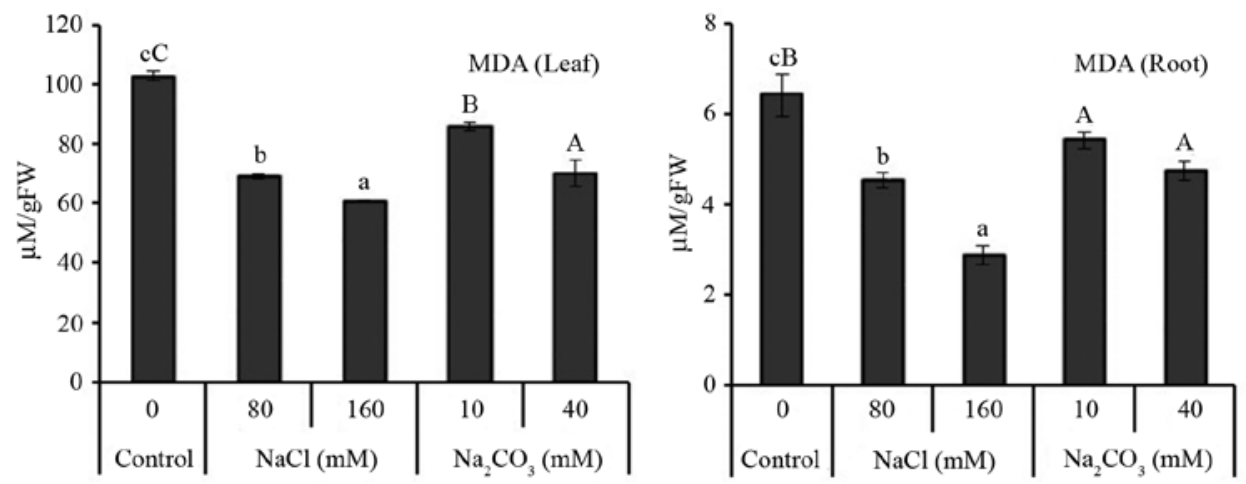

Fig. 2. Effect of two concentrations of $\mathrm{NaCl}$ and $\mathrm{Na}_{2} \mathrm{CO}_{3}$ on malondialdehyde (MDA) content of sunflower plant (35-day-old). The results are means of four replicates (+SE). Bars carrying different letters are significantly different at the 0.05 level

\section{Membrane damage}

$\mathrm{NaCl}$ and $\mathrm{Na}_{2} \mathrm{CO}_{3}$ at the lower concentration had a non-significant stimulatory effect on EC of sunflower leaves. However, the higher concentration had a significant stimulatory effect (Fig. 3). As another indicator for the degree of membrane damage, leaching of organic components in term of UV-absorbing metabolites was measured. UV-absorbing metabolites leakage from leaves discs was achieved at higher concentration of $\mathrm{NaCl}$ and $\mathrm{Na}_{2} \mathrm{CO}_{3}$ stresses, but the lower concentration of both applied salts failed to stimulate UV-absorbing metabolites (Fig. 3).
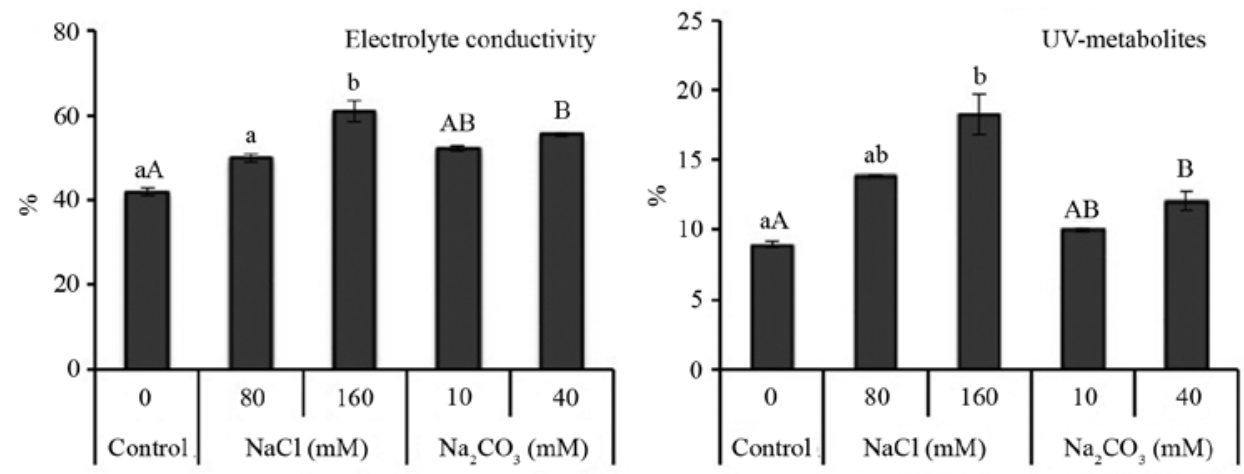

Fig. 3. Electrolyte conductivity (EC) \% and UV-metabolites \% of sunflower plant (35-day-old) as affected by two concentrations of $\mathrm{NaCl}$ and $\mathrm{Na}_{2} \mathrm{CO}_{3}$. The results are means of four replicates (+SE). Bars carrying different letters are significantly different at the 0.05 level 

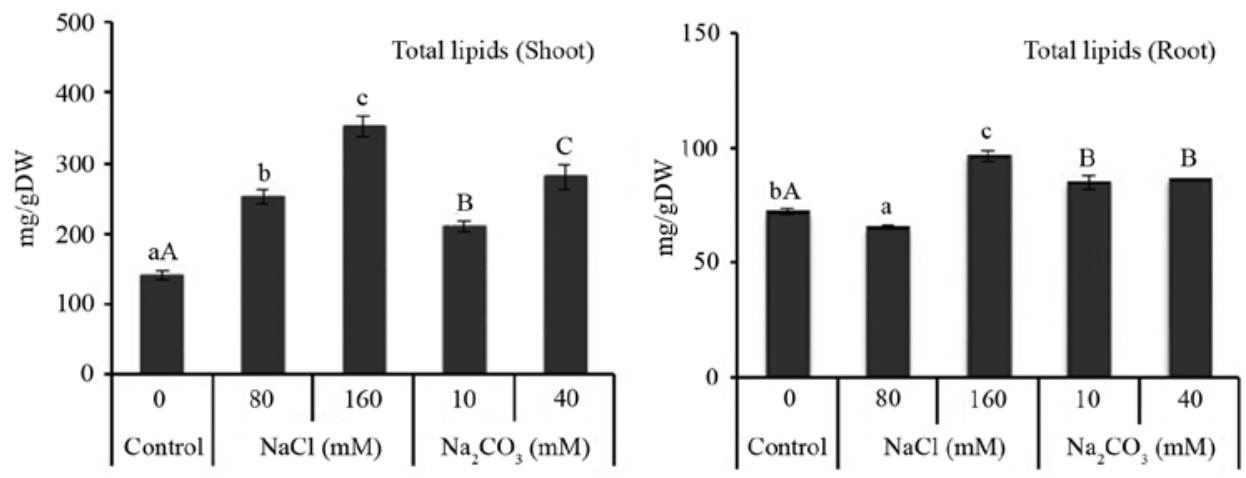

Fig. 4. Total lipids content in sunflower plant (35-day-old) as affected by two concentrations of $\mathrm{NaCl}$ and $\mathrm{Na}_{2} \mathrm{CO}_{3}$. The results are means of four replicates $(+\mathrm{SE})$. Bars carrying different letters are significantly different at the 0.05 level

\section{Total lipids}

In sunflower shoot and root, the lipids content was progressively increased by increasing $\mathrm{NaCl}$ or $\mathrm{Na}_{2} \mathrm{CO}_{3}$ level in the culture media, except in case of roots at 80 $\mathrm{mM} \mathrm{NaCl}$, where an opposite trend was exhibited (Fig. 4).

\section{Yield parameters and components}

$\mathrm{NaCl}$ and $\mathrm{Na}_{2} \mathrm{CO}_{3}$ reduced the yield parameters (plant height and head diameter) of sunflower plants with increasing the salt level; the lowest yield parameters were recorded at the higher concentration (Table 1). Also, a significant decrease in number of seeds and seed index with rise $\mathrm{NaCl}$ or $\mathrm{Na}_{2} \mathrm{CO}_{3}$ level were exhibited. The minimum seed number reached at the highest level of $\mathrm{Na}_{2} \mathrm{CO}_{3}(40 \mathrm{mM})$ (Table 1).

Table 1

Yield parameters and yield components of sunflower (120-day-old) plant as affected by two levels of $\mathrm{NaCl}$ and $\mathrm{Na}_{2} \mathrm{CO}_{3}$

\begin{tabular}{|l|c|c|c|c|c|}
\hline \multirow{2}{*}{\multicolumn{2}{|c|}{ Treatments $(m M)$}} & \multicolumn{2}{|c|}{ Yield parameters } & \multicolumn{2}{c|}{ Yield components } \\
\cline { 3 - 6 } & & Plant height & Head diameter & $\begin{array}{c}\text { Seed index } \\
(\mathrm{g} / 100 \text { seeds })\end{array}$ & No. of seeds/head \\
\hline \multirow{2}{*}{ Control } & $68.66 \pm 1.66^{\mathrm{bB}}$ & $10 \pm 0.57^{\mathrm{bB}}$ & $2.024 \pm 0.016^{\mathrm{bC}}$ & $47 \pm 0.86^{\mathrm{bC}}$ \\
\hline \multirow{2}{*}{$\mathrm{NaCl}$} & 80 & $66.33 \pm 1.45^{\mathrm{ab}}$ & $9 \pm 0.76^{\mathrm{ab}}$ & $1.8 \pm 0.002^{\mathrm{a}}$ & $38 \pm 3.78^{\mathrm{b}}$ \\
\cline { 2 - 6 } & 160 & $59.66 \pm 2.6^{\mathrm{a}}$ & $6.66 \pm 0.88^{\mathrm{a}}$ & $1.7 \pm 0.007^{\mathrm{a}}$ & $26 \pm 2.33^{\mathrm{a}}$ \\
\hline \multirow{2}{*}{$\mathrm{Na}_{2} \mathrm{CO}_{3}$} & 10 & $61.5 \pm 1.32^{\mathrm{A}}$ & $9.33 \pm 0.33^{\mathrm{AB}}$ & $1.77 \pm 0.03^{\mathrm{B}}$ & $31 \pm 3.48^{\mathrm{B}}$ \\
\cline { 2 - 6 } & 40 & $55.8 \pm 1.36^{\mathrm{A}}$ & $7.16 \pm 0.83^{\mathrm{A}}$ & $1.66 \pm 0.011^{\mathrm{A}}$ & $19 \pm 1.15^{\mathrm{A}}$ \\
\hline
\end{tabular}

The results are means of four replicates $(+\mathrm{SE})$. Different letters are significantly different at the 0.05 level 


\section{Fatty acids composition of seeds}

The major fatty acid methyl esters (FAME) in oil of sunflower seeds were oleic (C18:1), palmitic (C16:0) and stearic (C18:0) acids (Table 2). Lower concentration of $\mathrm{NaCl}$ stimulated the accumulation of saturated fatty acids (FAs), such as myristic, palmitic, stearic, arachidic, behenic and lignoceric, and unsaturated ones, palmitoleic and linoleic acids. In contrary, it significantly reduced oleic and inhibited linolenic, gondoic and tricosylic acids accumulation that weren't detected by GC/MS. At the higher salinity concentration, the accumulation of polyunsaturated FAs (linoleic, linolenic and gondoic) was increased, whereas myristic acid decreased. Alkalinity at lower concentration stimulated arachidic and behenic, but inhibited linoleic and linolenic acids accumulation. The higher concentration of $\mathrm{Na}_{2} \mathrm{CO}_{3}$ enhanced the accumulation of linolenic and gondoic, but reduced palmitic, linoleic, arachidic, behenic acids. Also, it reduced tricosylic acid to the level undetected by GC/MS. The data herein obtained reveal that the lower concentration of salinity significantly stimulated the saturated and polyunsaturated FAs, but inhibited the monounsaturated FAs accu-

Table 2

Effect of two levels of $\mathrm{NaCl}$ and $\mathrm{Na}_{2} \mathrm{CO}_{3}$ on fatty acid methyl esters (FAME) profile in oil of sunflower seeds (cv. Sakha 53)

\begin{tabular}{|l|l|c|c|c|c|c|}
\hline \multirow{2}{*}{$\begin{array}{c}\text { Fatty acids } \\
\%\end{array}$} & Control & \multicolumn{2}{c|}{$\mathrm{NaCl}(\mathrm{mM})$} & \multicolumn{2}{c|}{$\mathrm{Na}_{2} \mathrm{CO}_{3}(\mathrm{mM})$} \\
\cline { 2 - 7 } & 0 & 80 & 160 & 10 & 40 \\
\hline C14:0 & Myristic & $0.28048^{\mathrm{bA}}$ & $0.72613^{\mathrm{c}}$ & $0.1719^{\mathrm{a}}$ & $0.22018^{\mathrm{A}}$ & $0.2292^{\mathrm{A}}$ \\
\hline C16:0 & Palmitic & $14.7675^{\mathrm{aB}}$ & $38.3154^{\mathrm{b}}$ & $13.042^{\mathrm{a}}$ & $13.3403^{\mathrm{AB}}$ & $12.1951^{\mathrm{A}}$ \\
\hline C16:1 & Palmitoleic & $0.20203^{\mathrm{bAB}}$ & $1.04078^{\mathrm{c}}$ & $0.0694^{\mathrm{a}}$ & $0.08139^{\mathrm{A}}$ & $0.23811^{\mathrm{B}}$ \\
\hline C18:0 & Stearic & $7.45895^{\mathrm{aA}}$ & $24.3979^{\mathrm{b}}$ & $7.97894^{\mathrm{a}}$ & $9.06815^{\mathrm{A}}$ & $7.77475^{\mathrm{A}}$ \\
\hline C18:1 & Oleic & $71.9449^{\mathrm{bA}}$ & $14.6345^{\mathrm{a}}$ & $71.9717^{\mathrm{b}}$ & $70.8286^{\mathrm{A}}$ & $73.6121^{\mathrm{B}}$ \\
\hline C18:2 & Linoleic & $1.255156^{\mathrm{aB}}$ & $1.98475^{\mathrm{c}}$ & $1.4446^{\mathrm{b}}$ & $0.9318^{\mathrm{A}}$ & $0.99646^{\mathrm{A}}$ \\
\hline C18:3 & Linolenic & $0.10209^{\mathrm{aB}}$ & - & $0.16656^{\mathrm{b}}$ & $0.05948^{\mathrm{A}}$ & $0.1442^{\mathrm{C}}$ \\
\hline C20:0 & Arachidic & $0.81349^{\mathrm{aB}}$ & $3.14656^{\mathrm{b}}$ & $0.70362^{\mathrm{a}}$ & $1.06021^{\mathrm{C}}$ & $0.60584^{\mathrm{A}}$ \\
\hline C20:1 & Gondoic & $0.03439^{\mathrm{aA}}$ & - & $0.05659^{\mathrm{b}}$ & $0.04174^{\mathrm{A}}$ & $0.10008^{\mathrm{B}}$ \\
\hline C22:0 & Behenic & $1.44107^{\mathrm{aB}}$ & $5.97543^{\mathrm{b}}$ & $1.21291^{\mathrm{a}}$ & $1.8658^{\mathrm{C}}$ & $1.09116^{\mathrm{A}}$ \\
\hline C23:0 & Tricosylic & $0.15582^{\mathrm{aB}}$ & - & $0.14521^{\mathrm{a}}$ & $0.11374^{\mathrm{A}}$ & - \\
\hline C24:0 & Lignoceric & $0.3955^{\mathrm{aA}}$ & $1.77599^{\mathrm{b}}$ & $0.37049^{\mathrm{a}}$ & $0.50402^{\mathrm{A}}$ & $0.29592^{\mathrm{A}}$ \\
\hline S Saturated fatty acids & $25.3128^{\mathrm{aB}}$ & $74.3374^{\mathrm{b}}$ & $23.62507^{\mathrm{a}}$ & $26.1724^{\mathrm{B}}$ & $22.192^{\mathrm{A}}$ \\
\hline $\begin{array}{l}\text { Monounsaturated fatty } \\
\text { acids }\end{array}$ & $72.1813^{\mathrm{bAB}}$ & $15.6753^{\mathrm{a}}$ & $72.0977^{\mathrm{b}}$ & $70.9517^{\mathrm{A}}$ & $73.9503^{\mathrm{B}}$ \\
\hline $\begin{array}{l}\text { Polyunsaturated fatty } \\
\text { acids }\end{array}$ & $1.35724^{\mathrm{aB}}$ & $1.98475^{\mathrm{b}}$ & $1.61116^{\mathrm{a}}$ & $0.99128^{\mathrm{A}}$ & $1.14066^{\mathrm{AB}}$ \\
\hline
\end{tabular}

Values in the table are mean of fatty acid (as \% of FAME). Different letters are significantly different at the 0.05 level. 
mulation in sunflower seeds. However, the higher concentration of $\mathrm{NaCl}$ did not induce significant changes in saturated, monounsaturated and polyunsaturated FAs. Alkalinity stress at lower concentration did not affect the content of saturated and monounsaturated FAs, but reduced polyunsaturated acids content. With regard to the higher alkalinity concentration, monounsaturated and polyunsaturated acids did not change significantly, while saturated FAs exhibited a significant reduction.

\section{DISCUSSION}

Salt stress disturbs intracellular ion homeostasis of plants, which leads to membrane dysfunction, attenuation of metabolic activity, and causes growth inhibition and ultimately leads to cell death [31]. In the present study, the deleterious effects of $\mathrm{NaCl}$ and $\mathrm{Na}_{2} \mathrm{CO}_{3}$ salts on total dry matter gain in sunflower plant were clearly demonstrated and this effect is in agreement with previous investigation on sunflower [2]. The alkaline salts could cause damage to plants through both salt and $\mathrm{pH}$ stress [32]. In addition, plants growing under alkaline conditions suffer from the unavailability of some micronutrients essential to plant growth [3]. In plants, the LOX proteins play an important role in lipid peroxidation under biotic and abiotic stress, and involve in a number of developmental stages [18]. Moreover, LOX initiated the plant oxylipin pathway and produced jasmonic acid (JA), which participates in the defense responses against biotic and abiotic stresses [4]. In the current study, LOX activity was significantly decreased due to salinity or sodicity stress. Our results are in line with earlier findings, in achieving tolerance to drought, a lower level of LOX activity was recorded [7]. Moreover, lipid hydroperoxides produced by LOX served as substrates for stress-induced JA biosynthesis [28] without modifying membrane stability. In consistence with LOX activity a noticeable reduction in the MDA content was observed in leaves and roots of the $\mathrm{NaCl}$ and $\mathrm{Na}_{2} \mathrm{CO}_{3}$-stressed plant. Previous studies have shown that the lower level of lipid peroxidation in roots of two rice genotypes may be a response for protection against oxidative damage under salt stress [5]. The application of higher concentration of $\mathrm{NaCl}$ or $\mathrm{Na}_{2} \mathrm{CO}_{3}$ led to increase the $\mathrm{EC}$ rate in sunflower plant, this trend is consistent with previous study [37]. Moreover, supplement of $\mathrm{NaCl}$ or $\mathrm{Na}_{2} \mathrm{CO}_{3}$ increased the leakage of UV metabolites from leaves. Wahid et al. [36] reported that UV-absorbing metabolites increased by salinity.

Lipids are major components in membrane, which has main role in plant cell resistance in proportional to salt stress. In this investigation, the lipids content of shoots and roots progressively increased by increasing salts level, except in case of roots at $80 \mathrm{mM} \mathrm{NaCl}$ where an opposite trend was exhibited. In consist with our results, Gao et al. [8] found that key enzymes in the pathways of JA biosynthesis, lipid metabolism and indole-3-acetic acid homeostasis were up-regulated by salt stress in salt tolerance genotype. The total FAs concentration increased with salinity in leaves of two Crithmum maritimum Mediterranean genotypes [35].

Yield parameters and components of sunflower plant significantly reduced in response to the higher level of the applied salts. Parvaiz and Satyawati [24] docu- 
mented that the depressing effects of salt may be due to metabolic disorders, affecting the transportation of the necessary metabolites to the grains and hence lead to decrease yield, as found in the present study. Uma and Patil [33] concluded that reduction in seed number due to salt stress may be ascribed either to lesser number of ovule formation per ovary or failure in fertilization.

In this study, the dominant FAs in sunflower seeds were oleic, palmitic and stearic acids. A lower concentration of linoleic acid is more typical of the concentration expected in warmer southern latitudes [30]. There is a strong negative relationship between linoleic and oleic acids concentrations; i.e., if linoleic increases, oleic decreases [30]. This relationship is common in both wild and cultivated sunflower. Myristic, palmitic, stearic, arachidic, behenic, lignoceric, palmitoleic and linoleic acids in sunflower seeds oil were stimulated by the lower concentration of salinity, whereas oleic reduced and linolenic, gondoic and tricosylic acids dropped to the level undetected by GC/MS. While, higher concentration of salinity enhanced linoleic, linolenic and gondoic and reduced myristic acid accumulation in seeds. Also, our results reveal that the lower concentration of salinity increased the saturated and polyunsaturated acids and decreased the monounsaturated FAs due to oleic acid decrease; however the higher concentration of $\mathrm{NaCl}$ did not induce significant change in FAs. With regard to alkalinity at lower concentration stimulated arachidic and behenic, but inhibited linoleic and linolenic acids accumulation. The higher concentration of $\mathrm{Na}_{2} \mathrm{CO}_{3}$ enhanced the accumulation of linolenic and gondoic, but reduced palmitic, linoleic, arachidic, behenic and tricosylic acids. Also, alkalinity stress did not change the FAs composition of sunflower seeds oil, except polyunsaturated FAs of seeds at $10 \mathrm{mM}$ and saturated acids at $40 \mathrm{mM}$ exhibited a significant reduction. Salt stress reduced seed oil quality, which is similar to what as previously in two sunflower lines, Hysun-33 and SF-187 [23]. Experiments with transgenic tobacco cells and plants demonstrated that overexpression of $\omega-3$ desaturases, which increases 18:3, increases tolerance to salt and drought stress [38]. A two-phase growth response to salinity model was proposed by salinity [21] which states that water deficits inhibit growth shortly after salinization followed by ionic effects. Lower oleic acid in seeds under lower concentration of salinity may be possible to water-deficit stress. Water-deficit stress causes degradative processes such as the inhibition of lipid biosynthesis [19], and stimulation of lipolytic and peroxidative activities [16] that are associated with decreased membrane lipid content.

Together, our results show that sunflower cv. Sakha 53 displayed a strong capacity to tolerate salinity and alkalinity stress. Indications for this are: (a) reduction in MDA content and LOX activity; (b) stimulation in total lipid content; (c) accumulation of oleic acid in seeds, suggesting a so far unknown capacity for adaptation to salt stress.

\section{REFERENCES}

1. Avinash, M., Bhavanath, J. (2011) Antioxidant response of the microalga Dunaliella salina under salt stress. Bot. Mar. 54, 195-199. 
2. Azachi, M., Sadka, A., Fisher, M., Goldshlag, P., Gokhman, I., Zamir, A. (2002) Salt induction of fatty acid elongase and membrane lipid modifications in the extreme halotolerant alga Dunaliella salina. Plant Physiol. 129, 1320-1329.

3. Cardarelli, M., Rouphael, Y., Rea, E., Colla, G. (2010) Mitigation of alkaline stress by arbuscular mycorrhiza in zucchini plants grown under mineral and organic fertilization. J. Plant Nutr. Soil Sc. 173, 778-787.

4. Cho, K. Y., Kim, C., Woo, J. C. (2012) Transgenic expression of dual positional maize lipoxygenase-1 leads to the regulation of defense-related signaling molecules and activation of the antioxidative enzyme system in rice. Plant Sci. 185-186, 238-245.

5. Demiral, T., Türkan, I. (2005) Comparative lipid peroxidation, antioxidant defense systems and proline content in roots of two rice cultivars differing in salt tolerance. Environ. Exp. Bot. 53, 247-257.

6. Di Caterina, R., Giuliani, M., Rotunno, T., De Caro, A., Flagella, Z. (2007) Influence of salt stress on seed yield and oil quality of two sunflower hybrids. Ann. Appl. Biol. 151, 145-154.

7. Egert, M., Tevini, M. (2002) Influence of drought on some physiological parameters symptomatic for oxidative stress in leaves of chivs (Allium schoenoprasum). Environ. Exp. Bot. 48, 433-449.

8. Gao, R., Duan, K., Guo, G., Du, Z., Chen, Z., Li, L., He, T., Lu, R., Huang, J. (2013) Comparative transcriptional profiling of two contrasting barley genotypes under salinity stress during the seedling stage. Int. J. Genomics, 1-19.

9. Guo, L. Q., Shi D. C., Wang, D. L. (2010) The key physiological response to alkali stress by the alkali-resistant halophyte Puccinellia tenuiflora is the accumulation of large quantities of organic acids and into the rhyzosphere. J. Agron. Crop Sci. 196, 123-135.

10. Hoagland, D. R., Arnon, D. I. (1950) The water-culture method for growing plants without soil. California Agric. Exp. Station Cir., pp. 347.

11. Inouye, L. S., Lotufo, G. R. (2006) Comparison of macro-gravimetric and micro-colorimetric lipid determination methods. Talanta 70, 584-587.

12. Liu, J., Guo, W., Shi, D. (2010) Seed germination, seedling survival, and physiological response of sunflowers under saline and alkaline conditions. Photosynthetica 48, 278-286.

13. Liu, X. Y., Li, B., Yang, J. H., Sui, N., Yang, X. M., Meng, Q. W. (2008) Overexpression of tomato chloroplast omega-3 fatty acid desaturase gene alleviates the photoinhibition of photosystems 2 and 1 under chilling stress. Photosynthetica 46, 185-192.

14. Madhava Rao, K., Sresty, T. (2000) Antioxidative parameters in the seedlings of pigeonpea (Cajanus cajan (L.) Millspaugh) in response to $\mathrm{Zn}$ and Ni stresses. Plant Sci. 157, 113-128.

15. MALR (2009) Ministry of Agriculture and Land Reclamation. Agriculture Statistic "brief". Center Administration of Agriculture Economics.

16. Matos, A. R., d'Arcy-Lamet, A., Franca, M., Zuily-Fodil, Y., Pham-Thi, A. T. (2000) A patatin-like protein with galactolipase activity is induced by drought stress in Vigna unguiculata leaves. Biochem. Soc. Trans. 28, 779-781.

17. Minguez-Mosquera, M., Jaren-Galan, M., Garrido-Fernandez, J. (1993) Lipoxygenase activity during pepper ripening and processing of paprika. Phytochemistry 32, 1103-1108.

18. Molassiotis, A., Sotiropoulos, T., Tanou, G., Diamantidis, G., Therios, I. (2006) Boron-induced oxidative damage and antioxidant and nucleolytic responses in shoot tips culture of the apple rootstock EM 9 (Malus domestica Borkh). Environ. Exp. Bot. 56, 54-62.

19. Monteiro de Paula, F., Pham-Thi, A. T., Zuily-Fodil, Y., Ferrari-Iliou, R., Vieira da Silva, J., Mazliak, P. (1993) Effect of water stress on the biosynthesis and degradation of polyunsaturated lipid molecular species in leaves of Vigna unguiculata. Plant Physiol. Biochem. 31, 707-715.

20. Munns, R. (2002) Comparative physiology of salt and water stress. Plant Cell Environ. 25, 239-250.

21. Munns, R. (1993) Physiological processes limiting plant growth in saline soils: some dogmas and hypotheses. Plant Cell Environ. 16, 15-24.

22. Navari-Izzo, F., Izzo, R., Quartacci, M., Lorenzini, G. (1989) Growth and solute leakage in Hordeum vulgare exploded to long-term fumigation with low concentration of $\mathrm{CO}_{2}$. Physiol. Plant. 76, 445 450 
23. Noreen, S., Ashraf, M. (2010) Modulation of salt ( $\mathrm{NaCl}$ )-induced effects on oil composition and fatty acid profile of sunflower (Helianthus annuus L.) by exogenous application of salicylic acid. J. Sci. Food Agric. 90, 2608-2616.

24. Parvaiz, A., Satyawati, S. (2008) Salt stress and phyto-biochemical responses of plants. Plant Soil Environ. 54, 89-99.

25. Premachandra, G. S., Saneoka, A. H., Fujta, K., Ogata, S. (1992) Leaf water relations, osmotic adjustment, cell membrane stability, epicuticular wax load and growth as affected by increasing water deficits in sorghum. J. Exp. Bot. 43, 1569-1576.

26. Rasool, S., Hameed, A., Azooz, M., Siddiqi, T., Ahmad, P. (2012) Salt stress: causes, types and responses of plants. In: Ahmad, P. A. M., Prasad, M. N. V. (eds). Ecophysiology and responses of plants under salt stress. Springer, Berlin-New York, pp. 1-24.

27. Rauf, S., Munir, H., Sadaqat, H. A. (2008) Growing sunflower with insufficient water. Money Plus. $16-17$.

28. Rosahal, S. (1996) Lipoxygenases in plants-their role in development and stress responses. Z. Naturforsch. 51 c, 123-138.

29. Sairam, R. K., Rao, K. V., Srivastava, G. (2002) Differential response of wheat genotypes to long term salinity stress in relation to oxidative stress, antioxidant activity and osmolyte concentration. Plant Sci. 163, 1037-1046.

30. Seiler, G. J. (1986) Analysis of the relationships of environmental factors with seed oil and fatty acid concentrations of wild annual sunflower. Field Crops Res. 15, 57-72.

31. Sheokand, S., Bhankar, V., Sawhney, V. (2010) Ameliorative effect of exogenous nitric oxide on oxidative metabolism in $\mathrm{NaCl}$ treated Chickpea plants. Braz. J. Plant Physiol. 22, 81-90.

32. Shi, D., Sheng, Y. (2005) Effect of various salt-alkaline mixed stress conditions on sunflower seedlings and analysis of their stress factors. Environ. Exp. Bot. 54, 8-21.

33. Uma, M. S., Patil, B. C. (1996) Inter species variation in the performance of cotton under soil salinity stress. Kamataka J. Agric. Sci. 9, 73-77.

34. Van Handel, E. (1985) Rapid determination of total lipids in mosquitoes. J. Am. Mosq. Control. Assoc 1, 302-304.

35. Ventura, Y., Myrzabayeva, M., Alikulov, Z., Omarov, R., Khozin-Goldberg, I., Sagi, M. (2014) Effects of salinity on flowering, morphology, biomass accumulation and leaf metabolites in an edible halophyte. AoB Plants 6, 1-11.

36. Wahid, A., Perveen, M., Gelani, S., Basra, S. (2007) Pretreatment of seed with $\mathrm{H}_{2} \mathrm{O}_{2}$ improves salt tolerance of wheat seedlings by alleviation of oxidative damage and expression of stress proteins. J. Plant Physiol. 164, 283-294.

37. Yang, C., Chong, J., Li, C., Kim, C., Shi, D., Wang, D. (2007) Osmotic adjustment and ion balance traits of an alkali resistant halophyte Kochia sieversiana during adaptation to salt and alkali conditions. Plant Soil 294, 263-276.

38. Zhang, M., Barg, R., Yin, M., Gueta-Dahan, Y., Leikin-Frenkel, A., Salts, Y., Shabtai, S., BenHayyim, G. (2005) Modulated fatty acid desaturation via overexpression of two distinct $\omega-3$ desaturases differentially alters tolerance to various abiotic stresses in transgenic tobacco cells and plants. Plant J. 44, 361-371. 